\title{
Efektivitas Pelaksanaan Bantuan Sosial Dari Pemerintah Terhadap Masyarakat Terdampak Covid-19 Di Desa Gendongarum Kecamatan Kanor Kabupaten Bojonegoro
}

\section{The Effectiveness Of The Implementation Of Social Assistance On Communities Affected By Covid-19 In The Village Of Gedongarum Kanor District Bojonegoro District}

\author{
Fatkhul Khoiriyah, Liana Oktavia, Ni'matus Zakiyah, dan Muhammad Afthon Ilman Huda \\ Program Studi Hukum Keluarga Islam, Fakultas Syariah dan Hukum, \\ Universitas Islam Negeri Sunan Ampel \\ email: fatkhul.khoiriyah27@gamil.com, lianaoktavial1101998@gmail.com, nikmatuszakiyaho1@gmail.com, \\ aftonilman1999@gmail.com
}

\begin{abstract}
Abstrak
Penelitian ini dilakukan akibat adanya fenomena wabah Covid-19 yang terjadi diseluruh negara termasuk Indonesia. Yang menyebabkan pengaruh signifikan di berbagai sektor, termasuk sektor perekonomian. Hal tersebut menyebabkan Pemerintah melakukan berbagai upaya untuk mengurangi beban dimasyarakat, yaitu dengan memberikan bantuan sosial. Urgensi penelitian ini sebagai ukuran keefektivan program bantuan sosial di masa pandemi Covid-19 agar menjadi bahan evaluasi untuk dapat mengcover bantuan kepada masyarakat yang terdampak. Tujuan dilakukannya penelitian adalah untuk memperoleh pengetahuan mengenai penyaluran dana bantuan Covid-19 dan untuk menganalisai keefektivitasan pelaksanaan bantuan di Desa Gedongarum. Jenis penelitian ini adalah penelitian kualitatif. Dalam melakukan penelitian, penulis mendapatkan informasi dengan melakukan observasi tentang proses penyaluran bantuan, wawancara dengan masyarakat desa Gedongarum dimulai dari perangkat desa, petugas penyalur bantuan, masyarakat penerima bantuan, masyarakat non bantuan, dan melakukan dokumentasi. Hasil dari penelitian ini adalah bahwa pelaksanaan bantuan sosial di desa Gedongarum belum efektif
\end{abstract}

Kata Kunci: efektivita; bantuan sosial; covid-19

\begin{abstract}
The study was based on Covid-19 outbreak phenomena that occurred across countries including Indonesia. Causing significant impacts across sectors, including economic sectors. This causes governments to make efforts to reduce the burden on the community by providing social assistance. The urgency of this study is an effectiveness in a social assistance program during the covid-19 pandemic so that it can provide an evaluation to cover relief to affected communities.. The purpose of research is to gain knowledge about the distribution of covid-19 relief funds and to analyze the effectiveness of relief efforts in the village of gedongarum. This type of research is qualitative. In doing research, authors get information by observing the aid distribution process, interviews with village people of gedongarum starting with village tools, aid suppliers officers, relief recipients, relief recipients, non assistance communities, and documenting. The result of this study is that the administration of social assistance in the village of gedongarum has not been effective.
\end{abstract}

Keywords: effectiveness; sosial assistance; covid-19 


\section{Pendahuluan}

Covid-19, singkatan dari Coronavirus Disease 2019 yang dapat diartikan sebagai penyakit yang menyerang saluran pernapasan manusia. Saat ini, dunia tengah berjuang melawan pandemic Covid-19 ini, tentu bukan hal yang mudah terlebih lagi virus ini sangat cepat menular. Hingga hari ini $(29 / 6 / 2020)$ berdasarkan data dari laman Worldmeters, total kasus Covid-19 di dunia mencapai 10,250,322 kasus yang mana sebanyak 5,558,161 telah sembuh dan 504,498 orang meninggal dunia. Sedangkan di Indonesia sendiri kasus yang sudah terkonfirmasi sebanyak 54,010 kasus dengan angka kematian mencapai 2,754 kasus dan angka sembuh sebanyak 22,936. Pertama kali munculnya Covid-19 di Indonesia, DKI Jakarta menjadi daerah dengan jumlah kasus terbanyak. Akan tetapi, seiring berjalannya waktu (saat ini) angka positif Covid-19 tertinggi diduduki oleh Provinsi Jawa Timur dan Surabaya menjadi Kota yang paling banyak menyumbang. Bojonegoro juga menjadi salah satu wilayah dengan jumlah kasus yang cukup tinggi dan menjadi wilayah dengan zona merah yakni sebanyak 135 kasus yang dinyatakan positif dengan data terakhir diupdate pada tanggal 30 Juni 2020. Penyebaran Covid19 di Kabupaten Bojonegoro ini tersebar kedalam beberapa Kecamatan salah satunya Kanor dengan jumlah kasus yang masih terbilang sedikit yakni 2 kasus posistif ( 1 kasus dala perawatan dan 1 pasien dinyatakan sembuh). Didalam situs web Covid-19 Bojonegoro tidak ditampilkan 2 kasus tersebut berasal dari desa mana. Di Desa Gedongarum, berdasarkan pengamatan penulis belum ada warga yang dinyatakan positif Covid-19. Meski begitu, Covid-19 ini merupakan virus yang sangat cepat penyebarannya sehingga seluruh masyarakat di Desa Gedongarum harus tetap menerapkan protocol kesehatan agar kondisi desa tetap aman dan terhindar dari Covid-19 ini.

Pandemi yang pertama kali muncul di Kota Wuhan, Tiongkok, ini memberikan imbas yang besar pada perekonomian negara-negara di dunia termasuk Indonesia yang mana nantinya ekonomi global akan melambat dan akan sangat mempengaruhi dunia perindustrian. Beberapa dampak yang merugikan bagi dunia industri diantaranya: Pertama, tekanan besar yang dialami oleh perusahaan manufaktur otomotif yang mengakibatkan terhambatnya proses produksi. Kedua, sektor pariwisata, transportasi, perhotelan, restoran, dan lain-lain yang juga mengalami kerugian dan tidak berjalan dengan baik dikarenakan adanya kebijakan physical distancing, PSBB dan lain sebagainya. Ketiga, industri perfilman, media, dan pers yang harus menunda syuting, penayangan film, pencarian konten dan beritapun menjadi terhambat. Keempat, Sektor jasa yang mana mengabitkan orderan jasa menurun. Dan berbagai sector industri lainnya (Abdul Malik Ibrahim, 2020). Dampak-dampak diatas mengakibatkan banyak para pekerja yang terkena $\mathrm{PHK}$, penurunan penghasilan dan usaha-usaha yang mengalami kerugian bahkan harus menutup usahanya.

Berbagai upaya telah dilakukan oleh pemerintahan Indonesia untuk meminimalisir angka kasus positif Covid-19 ini yakni dengan cara penerapan phisical distancing, work form home (WFH), penggantian kegiatan belajar mengajar dari tatap muka menjadi daring kepada seluruh tingkat pendidikan baik formal maupun non formal, Pembatasan Sosial Berskala Besar (PSBB) dan berbagai upaya lainnya. Upaya-upaya tersebut terus diterapkan kepada seluruh masyarakat di Indonesia tanpa terkecuali meski pada akhirnya terjadi penurunan perekonomian. Dikutip dari situs bps.go.id, ekonomi Indonesia pada triwulan 1-2020 mengalami keterlambatan dibanding triwulan 1-2019 yakni dari 5,07 persen menjadi 2,97 persen. Selain penurunan ekonomi juga banyak pekerja yang di PHK, usaha-usaha yang terpaksa gulung tikar, penurunan penghasilan bagi para pedagang, ojek online, supir angkutan umum dan lain sebagainya. Semua lapisan masyarakat mengalami kerugian tersebut. 
Pemerintah selain melakukan kebijakan untuk penanganan medis, juga membuat berbagai program kebijakan yang bisa membantu masyarakat langsung. Berbagai bantuan diberikan kepada masyarakat dalam berbagai bentuk seperti uang tunai, sembako, atau pemotongan tagihan tarif listrik dan lain sebagainya yang pada saat seperti ini tentu banyak dibutuhkan oleh masyarakat yang terimbas dampak pandemi Covid-19 dan disalurkan dengan harapan dapat mencukupi kebutuhan sehari-hari. Tujuan utama dari adanya bantuan-bantuan tersebut adalah untuk menjamin ketersediaan kebutuhan dasar serta perlindungan sosial terutama bagi kelompok rentan yang terdampak dari adanya pandemi Covid-19 ini. Kelompok rentan yang dimaksud adalah para pekerja yang tidak menentu dalam hal jam kerja, kontrak, lingkup serta jaminan (Arika Bagus P et al, 2020, 6). Banyaknya para pekerja yang di PHK akan menambah jumlah kelompok rentan di Indonesia.Sebelum adanya pandemi Covid-19 ini masyarakat rentan memperoleh banyak bantuan dari pemerinah. Namun semenjak munculnya pandemi ini pemerintah mengeluarkan bantuan sosial khusus. Bantuan sosial khusus ini perlu dikeluarkan karena banyaknya pekerja informal yang mengalami penurunan drastis bahkan sampai kehilangan penghasilan akibat kebijakan-kebijakan yang ada, semakin bertambahnya kelompok rentan dikarenakan banyak perusahaan yang memutus hubungan kerja dengan para pekerjanya (Lestary J. Barany et al, 2020, 3) serta penurunan kemampuan daya beli masyarakat terhadap pemenuhan kebutuhan sehari-hari.

Dikutip dari website resmi Sekretariat Kabinet Republik Indonesia, Pemerintah telah membuat berbagai program bantuan berupa: Satu, Pemberian PKH (Program Keluarga Harapan) kepada 10 juta keluarga penerima dengan total anggaran sebanyak Rp. 37,4 Triliun. Kedua, Pemberian Kartu Sembako kepada 20 juta penerima yang mana setiap orang menerima bantuan tersebut sebesar Rp. 200.000 perbulan. Ketiga, penerbitan kartu prakerja kepada 5,6 juta orang dengan memberikan insentif setelah pelatihan sebesar Rp. 600.000 selama 4 bulan. Keempat, pemberian diskon tarif listrik untuk 900 VA dan pembebasan tariff listrik 450 VA. Kelima, bantuan sosial yang dibagi menjadi 3 (bantuan khusus bahan pokok sembako untuk masyarakat di DKI Jakarta, bantuan sembako untuk masyarakat di Bogor, Depok, Tangerang, dan Bekasi, dan bantuan sosial langsung tunai (BST) untuk masyarakat di luar Jabodetabek) yang mana jumlah bantuan tersebut sama, senilai Rp. 600.000 dan diberikan selama 3 bulan dan akan diperpanjang. Keenam, pengalokasian dana desa untuk bantuan sosial di desa selama 3 bulan sebesar Rp.600.000 tiap bulannya untuk 10 juta keluarga penerima, dan bantuanbantuan lainnya. Dari berbagai bentuk bantuan tersebut, penulis fokus meneliti mengenai 2 jenis bantuan yakni BST dan pengalokasian dana desa untuk bantuan sosial selama pandemi atau yang disebut BLT-Dana Desa yang mana keduanya bernilai sama Rp. 600.000 dan akan disalurkan selama 3 bulan. Kabupaten/Kota yang menjadi sasaran dari penerimaan bantuan tersebut adalah Kabupaten Bojonegoro. Dan Desa Gedongarum menjadi salah satu desa yang meyalurkan bantuan tersebut kepada warganya. Syarat utama dari penerima BST dn BLT-Dana Desa adalah mereka yang bukan penerima Bansos PKH dan Bansos Sembako. Penyaluran bantuan di Desa Gedongarum sudah berjalan selama 3 bulan, para warga sudah merasakan efek dari bantuan tersebut. Akan tetapi, data yang dimiliki baik oleh pusat dan daerah yang diguankan sebagai data sasaran penerima bantuan sosial dapat berpotensi tidak tepat sasaran, sebab pada umumnya data yang ada telah usang dan tidak relevan lagi dengan orang yang membutuhkan bantuan saat ini. Bahwa masyarakat yang tidak mendapatkan bantuan juga membutuhkan bantuan tersebut mengingat Covid-19 memiliki dampak luas dibidang ekonomi.

Pemerintah membentuk program bantuan selama Covid-19 mempunyai tujuan yang ingin diraih seperti yang telah dijelaskan diatas. Untuk melihat indikator tercapainya tujuan 
dari program bansos tersebut dalam membantu masyarakat rentan yang terdampak Covid-19 dapat diukur melalui efektivitas pelaksanaam program bansos tersebut. Pengukuran dapat dilakukan dengan cara membandingkan antara rancangan yang sudah ditetapkan dengan hasil nyata yang telah diwujudkan. Tindakan yang dilakukan harus tepat karena tujuan tidak akan tercapai atau dengan kata lain bantuan tidak efektif jika tindakan tersebut tidak tepat.

Efektivitas diartikan sebagai suatu ukuran yang dapat menggambarkan sejauh mana target dapat tercapai. keefektifan suatu program dapat diamati dari indikator-indikator berupa ketepatan penentuan pilihan, waktu, tujuan dan sasaran. Oleh karena itu, pengukuran efektivitas perilu dilakukan karena nantinya akan terlihat seberapa efektif bansos tersebut dalam memberikan kontribusi terhadap kehidupan masyarakat selama pandemi Covid-19 ini masih ada.

Berlandaskan paparan permasalahan dalam program BLT selama Covid-19 diatas, dapat diketahui bahwa supaya program ini bergerak optimal sesuai tujuan maka perlu adanya pengukuran efektivitas. Oleh karena itu, penulis tertarik untuk meneliti tentang Bantuan Sosial selama Covid-19 ini ada khusunya di Desa Gedongarum, Kecamatan Kanor, Kabupaten Bojonegoro. Dalam hal ini, penulis mengangkat judul "Efektifitas Pelaksanaan Bantuan Sosial dari Pemerintah Terhadap Masyarakat Terdampak Covid-19 (Studi Kasus di Desa Gedongarum, Kecamatan Kanor, Kabupaten Bojonegoro)"

Rumusan masalah yang didapat dari permasalahan diatas yaitu: Bagaimana pelaksanaan bantuan sosial dari Ppmerintah terhadap masyarakat terdampak Covid-19 di Desa Gendongarum Kecamatan Kanor Kabupaten Bojonegoro dan bagaimana efektivitas pelaksanaan bantuan sosial dari pemerintah terhadap masyarakat terdampak Covid-19 di Desa Gendongarum Kecamatan Kanor Kabupaten Bojonegoro

Tujuan dari penelitian ini adalah mengetahui Pelaksanaan Bantuan Sosial dari Pemerintah terhadap Masyarakat Terdampak Covid-19 di Desa Gendongarum Kecamatan Kanor Kabupaten Bojonegoro dan menganalisis Efektivitas Pelaksanaan Bantuan Sosial dari Pemerintah terhadap Masyarakat Terdampak Covid-19 di Desa Gendongarum Kecamatan Kanor Kabupaten Bojonegoro.

\section{Metode}

Desain penelitian yang digunakan dalam penelitian ini adalah penelitian deskriptif dengan menggunakan pendekatan kualitatif. Pendekatan kualitatif bermakna bahwa peenelitian yang dilakukan menggunakan konteks alamiah dengan tujuan untuk mengartikan apa yang terjadi dan dilakukan dengan berbagai metode yang ada (Albi Anggito \& Johan Setiawan, 2018, 7). Penelitian ini sering disebut dengan penelitian lapangan yang mana bersifat deskriptif, yaitu untuk memberikan data dari adanya Proses Pelaksanaan bantuan sosial dari pemerintah bagi masyarakat yang terdampak Covid-19 yang terjadi di Desa Gedongarum Kecamatan Kanor Kabupaten Bojonegoro Yakni dengan mempertegas hipotesa-hipotesa masyarakat yang menganggap bahwa implementasi dari pelaksanaan bantuan selama Covid-19 ini tidak terarah dan tidak tepat sasaran. Sumber data dalam penelitian berasal dari data primer dan sekunder. Adapun data primer memuat data yang berasal dari sumber pertama dalam penelitian ini yakni: 
1. Purwanto, Sebagai Kepala Desa Gedongarum Kecamatan Kanor Kabupaten Bojonegoro

2. Mustafidah, Sebagai Perangkat Desa Gedongarum Kecamatan Kanor Kabupaten Bojonegoro

3. Siti Surwani, Sebagai Petugas Penyalur Bantuan di Desa Gedongarum Kecamatan Kanor Kabupaten Bojonegoro

4. Legimah, Sebagai warga Desa Gedongarum yang mendapatkan BST melalui Kantor Pos

5. Sarmini, Sebagai warga Desa Gedongarum yang mendapatkan BLT-Dana Desa

6. Kusnah, Sebagai warga Desa Gedongarum yang mendapatkan BST melalui Rekening

Sedangkan untuk data sekunder berasal dari buku-buku, jurnal, artikel, data internet, dan data-data lainnya yang berhubungan dengan objek penelitian.

Adapun teknik pengumpulan data yang penulis gunakan adalah observasi, wawancara dan dokumentasi. Setelah data terkumpul maka data yang telah dikumpulkan dianalisis secara analisis deduktif yakni suatu pembahasan yang dilakukan dengan cara menganalisa teori Efektivitas sebagai landasan adanya analisis. Dalam hal itu dilakukan dengan cara menganalisis keefektifan proses pelaksanaan bantuan sosial dari pemerintah terhadap masyarakat yang terdampak Covid-19 di Desa Gendongarum Kecamatan Kanor Kabupaten Bojonegoro.

\section{Hasil dan Pembahasan}

Selama pandemi Covid-19 ini muncul, berbagai bentuk bantuan disalurkan baik oleh pemerintah pusat ataupun pemerintah daerah untuk masyarakat di desa Gedongarum. Bantuan-bantuan ini sangat membantu bagi para masyarakat yang terdampak dari adanya Pandemi Covid-19 ini. BST dan BLT-Dana Desa merupakan 2 jenis bantuan yang berbentuk tunai dan hingga saat ini penyalurannya sudah berjalan selama 3 bulan. Kedua bantuan tersebut dijelaskan sebagai berikut:

1. Bantuan Langsung Tunai Dana Desa (BLT-Dana Desa)

Dalam pasal 1 angka 28 Peraturan Menteri Desa PDTT No. 6 Tahun 2020 tentang perubahan atas Peraturan Menteri Desa, PDTT Nomor 11 Tahun 2019 tentang Prioritas Penggunaan Dana Desa Tahun 2020 dijelaskan tentang Bantuan Langsung Tunai Dana Desa yang disingkat dengan BLT-Dana Desa adalah pemberian uang tunai kepada keluarga yang tidak mampu atau miskin di desa untuk meringankan beban perekonomian sebagai imbas akibat pandemic Covid-19. Desa mempunyai sumber daya sosial dan ekonomi dan dapat berkontribusi dalam penanganan Covid-19, terutama pada Anggaran Pendapatan dan Belanja Desa (APBDes) dan Dana Desa. Dana Desa merupakan alokasi anggaran $O n$ Budget yang dapat digunakan langsung untuk mengurangi bencana dampak dari Covid-19 di tingkat rumah tangga. dan Desa (Priadi Asmanto et al, 2020).

Selanjutnya didalam Lampiran II PerMenDesa PDTT No. 6 Tahun 2020 Kriteria yang berhak dijadikan sebagai penerima BLT-Dana Desa/Bantuan Langsung Tunai dari Dana Desa yaitu keluarga miskin non Bantuan Pangan Non Tunai (BPNT) atau PKH yang berdomisili di desa yang bersangkutan, kehilangan mata pencaharian, belum terdata (Exclusion Error), dan didalam keluarga tersebut terdapat anggota keluarga yang rentan sakit kronis atau menahun. BLT Dana Desa perbulan sebesar Rp. 600.000,00 (enam ratus ribu rupiah) per keluarga, adapun cara melakukan pendataan dengan pertimbangan Data Terpadu Kesejahteraan Sosial (DTKS) dari Kementrian Sosial, yang dilakukan oleh kepala desa atau relawan desa lawan covid-19 dengan pendampingan dari PEMDA. Kepala desa beserta jajarannya dengan tanggap mengadakan musyawarah desa khusus atau musyawarah insidentil untuk pendataan warga yang berhak menerima BLT- 
Dana Desa tersebut. Legalitas dokumen hasil pendataan ditandatangani oleh kepala desa, kemudian oleh kepala desa di laporkan kepada bupati/walikota melalui perantara camat. Kegiatan dilakukan dalam kurun watku maksimal lima hari kerja ter tanggal sejak diterima di kecamatan. Untuk penyaluran BLT-Dana Desa akan berjalan selama 3 bulan terhitung sejak April 2020.

Dalam wawancara penulis dengan Ahmad Yasa' (23 Juni 2020) menyatakan bahwa para perangkat desa Desa Gedongarum telah melakukan musyawarah yang melibatkan DPD dalam hal penentuan penerima program BLT-Dana Desa ini. Desa Gedongarum menyalurkan BLT-Dana Desa ini kepada 26 KK dengan mengalokasikan dana desa sebesar 25\%. Adapun berikut adalah rincian penerima BLT-Dana Desa di Desa Gedongarum.

Tabel 1.

Jumlah Penerima BLT-Dana Desa

Desa Gendongarum Kecamatan Kanor Kabupaten Bojonegoro

\begin{tabular}{|c|c|c|c|}
\hline $\mathrm{NO}$ & DUSUN & $\mathrm{RT} / \mathrm{RW}$ & JUMLAH \\
\hline \multirow[t]{7}{*}{1.} & DONDONG & RT ol RW ol & 6 \\
\hline & & RT 02 RW 01 & 2 \\
\hline & & RT 03 RW 01 & 2 \\
\hline & & RT 04 RW 01 & 1 \\
\hline & & RT o1 RW 02 & 1 \\
\hline & & RT 02 RW 02 & 2 \\
\hline & & RT 03 RW 02 & 1 \\
\hline \multirow[t]{12}{*}{2.} & GEBANG & RT ol RW 03 & 1 \\
\hline & & RT 02 RW 03 & 1 \\
\hline & & RT 03 RW 03 & - \\
\hline & & RT 04 RW 03 & 2 \\
\hline & & RT 06 RW 03 & - \\
\hline & & RT 01 RW 04 & 2 \\
\hline & & RT 02 RW 04 & 1 \\
\hline & & RT 03 RW 04 & 1 \\
\hline & & RT 04 RW 04 & 1 \\
\hline & & RT 05 RW 04 & 2 \\
\hline & & RT 06 RW 04 & - \\
\hline & TOTAL & & 26 \\
\hline
\end{tabular}

Desa Gendongarum Kecamatan Kanor Kabupaten Bojonegoro, sejauh ini sudah dilakukan 3x pengambilan pertama di laksanakan pada tanggal 16 Mei 2020 yang bertempat di Kantor Kecamatan Kanor, kedua di laksanakan pada tanggal 14 Juni 2020 yang bertempat di Kantor Kecamatan Kanor dan pengambilan ketiga di laksanakan pada tanggal 11 Juli 2020 yang bertempat di Desa Sumberwangi Kecamatan Kanor Kabupaten Bojonegoro (wawancara dengan Siti Suwarni, 23 Juni 2020). Berdasarkan pernyataan salah satu warga desa Gedongarum yang telah menerima BLT-Dana Desa bahwa tiap bulannya bantuan tersebut selalu dibagikan, tidak ada keterlambatan hingga bulan berikutnya (wawancara dengan Sarmini, 24 Juni 2020) 
2. Bantuan Sosial Tunai (BST)

Berbeda halnya dengan BLT-Dana Desa yang diatur dalam Peraturan Menteri Desa, Pembangunan Daerah Tertinggal, dan Transmigrasi Rl No 6 Tahun 2020, tidak ada peraturan perundang-undangan yang mengatur secara detail terkait dengan BST. Aturan terkait dengan BST hanya ada didalam Keputusan Menteri Sosial Republik Indonesia Nomor 54/HUK/2020 Tentang Pelaksanaan Bantuan Sosial Sembako dan Bantuan Sosial Tunai dalam Penanganan Dampak Corona Virus Disease 2019 (Covid-19). Didalamnya diatur tekait dengan data keluarga penerima bantuan sosial tunai yang diutamakan berasala dari data terpadu kesejahteraan sosial dan bisa berasal dari usulan pemda kabupaten/kota.

Adapun syarat dari penerima BST adalah masyarakat yang masuk dalam pendataan RT/RW, kehilangan mata pencaharian selama pandemi Covid-19, tidak terdaftar dalam program bantuan sosial lainnya seperti PKH, BPNT, Kartu Sembako dan Kartu Prakerja (Nunik Dewi Pramanik, 2020, 115). Dikutip dari website resmi kemsos.go.id bahwa pendistribusian bantuan sosial tunai melalui rekening bank-bank Himabara dan PT. Pos Indonesia yang berstatus badan usaha milik negara. Untuk para penerima lewat kantro pos, mereka akan dipanggil dengan surat yang dibubui barcode. Kemudian ketika proses pengambilan mereka diharuskan menunjukkan KTP dan nantinya akan difoto. Sementara untuk rekening, bantuan tersebut akan dikirim langsung ke nomor rekening penerima dan bisa diambil di bank-bank yang telah bekerjasama.

Dalam wawancara penulis dengan Ahmad Yasa' (23 Juni 2020) memberikan pernyataan bahwa di Desa Gedongarum terdapat 97 KK yang menerima BST ini. 97 KK tersebut dibagi menjadi 2 instrumen penyaluran yakni Kantro pos dan Bank (BRI, BNI, dan Mandiri). Adapun berikut adalah rincian penerima BST di Desa Gedongarum.

Tabel 2.

Jumlah Penerima BST

Desa Gendongarum Kecamatan Kanor Kabupaten Bojonegoro

\begin{tabular}{|c|c|c|c|c|c|}
\hline \multirow[t]{2}{*}{ NO } & \multirow[t]{2}{*}{ DUSUN } & \multirow[t]{2}{*}{$\mathrm{RT} / \mathrm{RW}$} & \multirow[t]{2}{*}{ JUMLAH } & \multicolumn{2}{|c|}{$\begin{array}{l}\text { INSTRUMEN } \\
\text { PENYALURAN }\end{array}$} \\
\hline & & & & $\begin{array}{l}\text { KANTOR } \\
\text { POS }\end{array}$ & REKENING \\
\hline \multirow[t]{7}{*}{1.} & DONDONG & RT ol RW ol & 4 & 3 & 1 \\
\hline & & RT 02 RW o1 & 3 & 3 & - \\
\hline & & RT 03 RW ol & 4 & 2 & 2 \\
\hline & & RT 04 RW ol & 7 & 5 & 2 \\
\hline & & RT 01 RW 02 & - & - & - \\
\hline & & RT 02 RW 02 & 5 & 4 & 1 \\
\hline & & RT 03 RW 02 & 2 & 1 & 1 \\
\hline 2. & GEBANG & RT o1 RW 03 & 1 & 1 & - \\
\hline
\end{tabular}




$\begin{array}{lccc}\text { RT 02 RW 03 } & 4 & 2 & 2 \\ \text { RT 03 RW 03 } & 4 & 4 & - \\ \text { RT 04 RW 03 } & 8 & 5 & 3 \\ \text { RT 05 RW 03 } & 10 & 8 & 2 \\ \text { RT 06 RW 03 } & 10 & 4 & 6 \\ \text { RT 01 RW 04 } & 6 & 5 & 1 \\ \text { RT 02 RW 04 } & 4 & 3 & 1 \\ \text { RT 03 RW 04 } & 4 & 3 & 1 \\ \text { RT 04 RW 04 } & 4 & 3 & 1 \\ \text { RT 05 RW 04 } & 3 & 1 & 2 \\ \text { RT 06 RW 04 } & 14 & 6 & 8 \\ & 97 & 63 & 34\end{array}$

Bantuan Sosial Tunai ini sudah sangat membantu bagi mereka yang menerima. lbu Legimah, salah satu warga masyarakat Desa Gedongarum dari RT 02 RW 04 yang menerima bantuan melalui kantor pos mengakui bahwa BST ini sangat membantu untuk memenuhi keperluan hidupnya sepanjang masa pandemi Covid-19 ini. Berdasarkan keterangan lbu Legimah, dia mengambil pertama kali pada tanggal 16 Mei 2020 bertempat di kantor pos. dan untuk pengamblan tahap kedua berlokasi di Balai Desa Temu pada tanggal 14 Juni 2020. Saat pengambilan tahap kedua ini berdesak-desakan sehingga tidak ada jarak. Kemudian tahap ketiga pada tanggal 11 Juli 2020 berlokasi di Kantor pos. Saat pengambilan diharuskan membawa surat yang diberi oleh RT setempat dan terdapat barcode, KTP, KK dan nantinya akan difoto oleh petugas (wawancara dengan Legimah, 23 Juni 2020)

Selain itu, lbu Kusnah merupakan salah satu warga Desa Gedongarum yang juga menerima BST akan tetapi melalui rekening. Dalam wawancara penulis dengan Kusnah (24 Juni 2020) menyatakan bahwa tidak ada persyaratan apapun dari aparat desa karena pendataan berasal dari pusat. Tanggal pencairan bantuan lewat rekening sama dengan tanggal pencairan lewat kantor pos. Pengambilan dilakukan di bank-bank yang sudah ditentukan salah satunya Bank BRI yang digunakan oleh lbu Kusnah. Uang bantuan bisa diambil kapanpun jika memang membutuhkan dan tidak ada biaya tambahan untuk pengambilan uang bantuan sosial tersebut.

Dalam pelaksanaan suatu program terutama bantuan sosial yang langsung ditujukan untuk masyarakat yang membutuhkan tidak bisa dipungkiri pasti terdapat kekurangan. Apalagi, ketika dalam masa pandemic Covid-19 yang mana tentunya semua masyarakat tanpa terkecuali merasa terdampak dan ketika terdapat suatu masyarakat yang tidak mendapatkan BST/BLTDana Desa bisa menimbulkan kecemburuan sosial. Oleh karena itu, agar program bantuan 
sosial BST dan BLT-Dana Desa ini bisa lebih baik kedepannya, diperlukanlah pengukuran efektivitas suatu program.

Efektivitas berasal dari kata efektif yang dalam bahasa Inggris effective yang berarti berhasil atas sesuatu yang dilakukan dengan baik. Dalam KBBI diartikan sebagai pendayaguanaan dan kesesuiaan antara hasil yang dicapai dengan rencana yang disusun. Efektivitas adalah pendayagunaan sarana prasarana dan sumber daya dalam kuantitas tertentu yang secara sadar ditetapkan sebelumnya untuk menghasilkan sejumlah pekerjaan pada waktunya. Secara keseluruhan bisa disimpulkan bahwa suatu efektivitas program bisa dinilai dengan seberapa jauh peningkatan kesejahteraan masyarkat dengan diberlakukan program bantuan tersebut. Karena pada dasarnya efektivitas mengacu pada hasil pencapaian tujuan yang sesuai dengan rencana (Ririn Anjela, 2019, 9-11). Pemerintah melakukan berbagai upaya untuk membantu masyarakat pada masa pandemi Covid-19, untuk membantu masyarakat dan diharapkan program tersebut bisa berjalan dengan efektif. Efektivitas menunjukkan keberhasilan dari segi tercapai tidaknya sasaran yang telah ditetapkan jika hasil kegiatan semakin mendekati sasaran, berarti makin tinggi efektivitasnya.

Tingkat keefektivitasan sebuah program dapat diukur menurut berbagai sudut pandang tergantung bagaimana cara menilai dan mengimpretasikannya. Apabila suatu pekerjaan dan hasil usaha tidak mencapai sasaran yang diharapkan, bisa dikatakan bahwa hal tersebut belum efektiv, begitupun sebaliknya. Untuk mengukur keefektifan sebuah program dibutuhkan tiga indikator, diantaranya:

1. Pencapaian tujuan, yaitu segala bentuk upaya untuk mencapai tujuan harus dilihat sebagai suatu proses. Ada dua faktor, kurun waktu dan sasaran yang merupakan target nyata

2. Integrasi, yaitu mengukur tingkat kemampuan suatu organisasi untuk mengadakan sosialisasi atau komunikasi dan pengembangan konsekuensi, Integrasi menyangkut proses sosialisasi.

3. Adaptasi, yaitu kemampuan organisasi untuk menyesuaikan diri dengan lingkungannya. Berkaitan dengan kesesuaian antara program dengan keadaan dilapangan.

Berdasarkan teori efektivitas dan penelitian yang sudah dipaparkan diatas, bisa diamati bahwa efektivitas pelaksanaan program BST dan BLT-Dana Desa di Desa Gendongarum selama 3 bulan ini telah terealisasi dalam beberapa sisi keefektifan, diantaranya:

jika dilihat didalam Lampiran II Peraturan Menteri Desa, Pembangunan daerah Tertinggal, dan Transmigrasi Republik Indonesia Nomor 6 Tahun 2020 terkait dengan jangka waktu dan besaran BLT-Dana Desa yang menyatakan bahwa bantuan jenis ini akan diberikan kepada masyrakat selama 3 bulan dan paling cepat bulan april 2020. Begitu juga dengan BST yang tidak diatur dalam peraturan perundang-undangan akan tetapi didalam Keputusan Menteri Sosial Republik Indonesia Nomor 54/HUK/2020 Tentang pelaksanaan bantuan sosial sembako dan bantuan sosial tunai dalam penanganan dampak Corona Virus Disease 2019 (Covid-19).

Maka Desa Gedongarum sebagai salah satu desa yg melaksanakan program bantuan baik BST maupun BLT-Dana Desa telah melakukan penyaluran selama 3 tahap berawal dari bulan mei, juni dan juli. Untuk tanggal penerimaan bantuan baik BST ataupun BLT-Dana Desa Sehingga jika dilihat dari segi ketepatan waktu, penyaluran BST dan BLT-Dana Desa telah terlaksana dengan tepat waktu. Tidak ada penundaan hingga bulan berikutnya. sedangkan 
untuk tanggal pengambilan didalam peraturan tidak diatur secara jelas. Akan tetapi hal ini tidak menjadi permasalahan bagi warga yang menerima bantuan.

Pemilihan penerima bantuan sosial baik BST maupun BLT-Dana Desa tentu tidak akan bisa terhindar dari berbagai problematikanya. Persyaratan pokok dari penerima bantuan ini adalah masyarakat yang tidak menerima bantuan apapun berupa pkh, bpnt, ataupun sembako. Tujuannya tentu agar bantuan ini bisa merata bagi seluruh warga. Desa Gedongarum menjadi salah satu desa yang menyalurkan BST dan BLT-Dana Desa dengan jumlah 97 KK untuk penerima BST dan $26 \mathrm{KK}$ untuk BLT-Dana Desa. Masyarakat yang menerima bantuan tersebut diharapkan tidak mendapatkan bantuan lain. Akan tetapi, faktanya terdapat beberapa masyarakat yang mendapatkan bantuan ganda. Padahal adanya Covid-19 ini merugikan seluruh masyarakat di Desa Gedongarum tidak hanya beberapa orang saja. Hal tersebut mengakibatkan kecemburuan sosial. Tepat setelah penyaluran BST dan BLT-Dana Desa tahap pertama pada tanggal 16 Mei 2020 di Desa Gedongarum terdapat beberapa warga yang merasa tidak adil atas pembagian kedua bantuan tersebut. Warga tersebut benar-benar mengalami dampak yang cukup signifikan dari adanya pandemi Covid-19 ini yakni berupa penurunan penghasilan apalagi warga tersebut sudah menjadi janda dan harus menghidupi anak-anaknya yang kebutuhan saat pandemi seperti ini jelas lebih banyak yakni pembelian paket data yang digunakan untuk menunjang proses pembelajaran daring. Tapi justru ia tidak mendapatkan bantuan apapun baik BST, BLT-Dana Desa bahkan sembako. Sehingga menyebabkan beberapa warga tersebut protes kepada perangkat desa. Akibatnya perangkat desa memutuskan untuk membagikan sembako secara merata kepada seluruh masyarakat didesa Gedongarum tanpa terkecuali. Sembako ini berupa kebutuhan pokok yakni Beras $3 \mathrm{Kg}$, Minyak Goreng IL, Gula Pasir $1 \mathrm{Kg}$, Mie Instan 10 Bungkus yang dikeluarkan kepada tiap KK di desa Gedongarum. Sembako ini murni berasal dari dana desa Gedongarum diluar dana untuk penyaluran BLTDana Desa (wawancara dengan Ahmad Yasa', 23 Juni 2020)

Inisiatif para perangkat desa gedongarun sangatlah baik, karena dengan hal ini bisa sedikit mengurangi kecemburuan sosial akibat pembagian BST ataupun BLT-Dana Desa yang tidak tepat sasaran. Bantuan sembako ini hanya berjalan selama 1 bulan yakni pada bulan Mei meski hanya 1 bulan bantuan ini cukup membantu para warga yang protes tersebut. Kejadian tersebut menunjukkan bahwa pelaksanaan dari adanya BST dan BLT-Dana Desa ini masih belum berjalaan efektif. Penerimaan bantuan ganda tersebut disebabkan oleh penggunaan data yang belum diperbarui. Berdasarkan pernyataan dari para perangkat desa, untuk BST ini data yang digunakan adalah data langsung dari pihak pusat yakni dinas sosial yang mana data ini merupakan data terdahulu. Dalam wawancara penulis dengan Ahmad Yasa' ( 23 Juni 2020) menyatakan bahwa data yang digunakan merupakan data pada tahun 2013-2014 begitu juga dengan pernyataan Bapak Purwanto selaku kepala desa Gedongarum bahwa data yang digunakan sudah lama sehingga akan rawan terjadi konflik (wawanacara dengan Purwanto, 25 Juni 2020). Berdasarkan pernyataan tersebut data tahun 2013-2014 tersebut pun menjadi tidak relevan jika digunakan untuk saat ini. Karena realitanya terdapat masyarakat yang pada tahun 2013 memang kebutuhannya tidak tercukupi akan tetapi saat ini sudah berkecukupan meski tetap mengalami dampak pandemi Covid-19. Sehingga dapat terlihat jika kedua bantuan sosial tersebut memang belum mengcover seluruh kelompok rentan yang terdampak dari kemunculan pandemi Covid-19 ini.

Masalah lain yang muncul dalam proses pelaksanaan bantuan sosial ini dapat dilihat dari prosedur penentuan sasaran penerima BLT-Dana Desa. Desa Gedongarum telah melakukan 
prosedur pemilihan calon penerima BLT-Dana Desa sesuai dengan peraturan Peraturan Menteri Desa PDTT No. 6 Tahun. Dalam wawancara penulis dengan Ahmad Yasa' ( 23 Juni 2020) yang menyatakan bahwa perangkat desa telah melakukan musyawarah dengan DPD untuk menentukan siapa saja penerima dari BLT-Dana Desa ini. Akan tetapi, memang penyeleksian dari penerima bantuan langsung tunai dana desa ini sangat sulit dikarenakan kriteria penerima yg pada dasarnya jika dilihat dengan keadaan sekarang tidak relevan. Tidak ada warga yang memiliki kriteria dengan yang sudah ditentukan seperti penerangan tanpa listrik, luas tanah $4 \times 4 \mathrm{~m} 2$ dan 12 kriteria lainnya.

Akan tetapi, dikutip dari ombudsman.go.id bahwa berdasarkan klarifikasi kementrian desa jika pendataan tidak mnegacu pada 14 kriteria tersebut. Karena pada dasarnya pendataan calon penerima BLT-Dana Desa dilihat dari 3 kriteria pokok yang diatur didalam Peraturan Menteri Desa PDTT No. 6 Tahun 2020. Sedangkan untuk BST, data penerima berasal dari pusat sehingga perangkat desa di Desa Gedongarum hanya membantu proses penyaluran saja seperti pemberitahuan kepada masyarakat yang menerima ketika bantuan sosial tunai mereka telah cair. Akan tetapi berdasarkan pernyataan dari Bapak Ahmad Yasa', Bapak Purwanto dan lbu Suwarni untuk BST yang dikeluarkan oleh Kemensos di Desa Gedongarum ini tidak tepat sasaran. Karena data yang digunakan sudah lama dan berdasarkan pernyataan beberapa narasumber baik yang mendapatkan bantuan atau tidak, tidak pernah ada pendataan oleh perangkat desa. Padahal kemunculan pandemi Covid-19 ini menimbulkan kelompok-kelompok rentan lainnya yang sangat membutuhkan bantuan sosial untuk keberlangsungan hidup mereka.

Selain itu, saat proses penyaluran terdapat 2 bentuk instrumen untuk BST dan 1 bentuk untuk BLT-Dana Desa. Bentuk penyaluran BST dan BLT-Dana Desa ini juga menjadi ukuran efektivitas yang penting. Instrument penyaluran BST berjalan kurang efektif dikarenakan tidak adanya penerapan protokol kesehatan saat proses penyaluran bantuan sosial tunai yang dilakukan di balai desa tepatnya pada penyaluran tahap 11 tanggal 14 Juni 2020, Masyarakat yang datang untuk mengambil saling berdesakan bahkan ada yang tidak memakai masker. Kejadian tersebut bisa memunculkan klaster baru penyebaran pandemi Covid-19. Hal tersebut menmperlihatkan jika para petugas tidak melakukan pengawasan denga baik. Atas kejadian tersbut pada akhirnya penyaluran tahap 111 kembali dilakukan di kantor pos yg tentunya lebih efektif karena terdapat pembagian waktu pengambilan.

Selain pengambilan bantuan sosial tunai lewat kantor pos juga terdaoat pengabilan dengan isntrumen rekening. Dalam hal penyaluran rekening tentunya memiliki kelebihan dan kekurangan. Jika diamati instrumen penyaluran ini lebih efisien dikarenakan para penerima tidak harus mengantri dan tidak terdapag biaya admin. Akan tetapi terdapat salah satu penerima bst lewat rekening yang justru tidak mengambil bantuan tersebut sehingga pada akhirnya menumpuk. la hanya mengambil ketika memang benar-benar membutuhkan. Hal tersebut sepertu terliha jika masih ada penerima bantuan sosial tunai yang realitanya memang terdampak Covid-19 tapi masih bisa dikatakan sebagai keluarga yang mampu sehingga kurang layak untuk mendapatkan banfyan sosial tunai tersebut. Oleh karena itu, penggunaan rekening kurang begitu efektif terutama jika sasarannya juga tidak tepat.

Pada dasarnya permasalahan yang menjadi program BST dan BLT-Dana Desa di Desa Gedongarum kurang efektif adalah data yang tidak akurat dan tidak tepat sasaran karena tidak ada pembaharuan. Data yang tidak tepat sasaran bisa menimbulkan permasalah-permasalahn lainnya seperti yang sudah dijelaskan diatas. Dari seluruh narasumber di Desa Gedongarum 
menyatakan bahwa kedua bantuan tersebut kurang efektif bagi sebagian orang meski memang sangat membantu bagi masyarakat yang terdampak Covid-19 dan memperoleh bantuan tersebut. Meski hanya sebagian, jika permasalahan pokok ini tidak segera diatasi maka masyarakat Gedongraum akan memandang proram bantuan sosial ini bukan sebagai hal yang positif tetapi justru sebaliknya. Dan justru akan memicu konflik-konflik antar masyarakat karena terdapat kecemburuan sosial

Kunci agar permasalahan ini bisa teratasi adalah dengan pembaharuan data karena bantuan inipun akan diperpanjang. Sehingga nantinya baik BST maupun BLT-Dana Desa ini bisa mencakup seluruh kelompok rentan yang benar-benar membutuhkan. Peran masyarakat juga dibutuhkan yakni berupa penerima bantuan melakukan penilaian mandiri dengan cara: pertama, calon penerima bantuan harus tau apakah dia termasuk penerima program PKH atau tidak. Kedua, Pemahaman masyarakat terkait program-progam bantuan apa saja yang ada selama masa pandemi ini beserta perbedaanya dan tidak diperbolehkannya mendapatkan bantuan ganda (hanya boleh menerima 1 jenis bantuan). Ketiga, penerima bantuan bisa menjelaskan apakah dia mengalami dampak langsung atau tidak akibat adanya pandemi Covid19 ini dan mengalami kesulitan untuk membayar cicilan dan mencukupi kebutuhan sehari-hari (Renaldo Hendi, 2020). Selain itu, koordinasi yang baik antar pemerintah pusat dan pemerintah daerah yang baik harus dilakukan demi tercapainya tujuan dari bantuan sosial ini. Harus terdapat regulasi yang lebih detail terkait bansos ini dan tidak ada peraturan perundangundangan yang tumpang tindih. Hal-hal diatas diharapkan bisa mengurangi terjadinya polemik di masyarakat Desa Gedongarum yang disebabkan oleh tidak efektifnya pelaksanaan bantuan sosial yang disalurkan kepada masyarakat terdampak Covid-19 di Desa Gedongarum akibat dari tidak tepatnya sasaran penerima bantuan.

\section{Penutup}

Berdasarkan hasil dan pembahasan diatas dapat diambil kesimpulan bahwa Desa Gedongarum menjadi salah satu desa di Indonesia yang mendapat berbagai bentuk bantuan sosial selama pandemi Covid-19. Beberapa bantuan tersebut berupa tunai yang disebut dengan BST dan BLT-Dana Desa. Adapun jumlah dari penerima kedua bantuan tersebut adalah $26 \mathrm{KK}$ untuk BLT-Dana Desa dan 97 untuk BST. Akan tetapi tidak bisa dipungkiri bahwa suatu pemerintahan dalam melaksanakan suatu programnya terutama dalam masalah pemberian bantuan sosial yang langsung ditujukan untuk masyarakat yang membutuhkan pasti terdapat kekurangan. Apalagi, ketika dalam masa pandemi Covid-19 seperti ini, yang mana tentunya semua masyarakat tanpa terkecuali merasa terdampak dan ketika terdapat salah satu masyarakat yang tidak mendapatkan BST/BLT-Dana Desa bisa menimbulkan kecemburuan sosial. Dalam hal ini titik poin yang menjadi permasalahan dalam program BST dan BLT-Dana Desa di Desa Gedongarum Kecamatan Kanor Kabupaten Bojonegoro masih dirasa kurang efektif dalam hal kurangnya keakuratan data dan tidak tepat sasaran sebab tidak ada pembaharuan data. Oleh karena itu, perlunya suatu inisatif tersediri dari perangkat desa agar program bantuan sosial BST dan BLT-Dana Desa ini bisa lebih baik kedepannya. Maka perlu suatu adanya keefektivan pelaksanaan bantuan dalam suatu program yang mana bisa dinilai dengan seberapa jauh peningkatan kesejahteraan masyarakat dengan diberlakukan program bantuan tersebut.

\section{Referensi}

Arika Bagus P et al. (2020, April). Policy Analysis Melindungi Pekerja Rentan di Masa (dan Pasca) pandemic Covid-19", IGPA MAP FISIPOL UGM dan Forbil Institute. 
Ahmad Yasa', Wawancara, Desa Gedongarum Kecamatan Kanor Kabupaten Bojonegoro, 23 Juni 2020

Anggito, Albi dan Johan Setiawan. (2018). Metode Penelitian Kualitatif, Sukabumi: CV. Jejak.

Anjela, Ririn. (2019) "Efektivitas Bantuan Dana Tunai Program PKH Dalam Pemberdayaan Masyarakat Miskin Di Desa Kualu Kecamatan Tambang Kabupaten Kampar" SkripsiUIN Sultan Syarif Kasim, Riau.

“Covid-19 Coronavirus Pandemic" (2020, 29 Juni) dalam https://www.worldometers.info/coronavirus/.

"Data Pemantauan Covid-19 Kabupaten Bojonegoro" (2020, 29 Juni) dalam http://lawancorona.bojonegorokab.go.id/data/.

Daton, Darius Beda. (2020, 20 Juli). "Kusut Data BLT Dana Desa", dalam https://ombudsman.go.id/artikel/r/artikel--kusut-data-blt-dana-desa.

"Ekonomi Indonesia Triwulan 12020 Tumbuh 2,97 Persen" (2020, 30 Juni) dalam https:/www.bps.go.id/pressrelease/2020/05/05/1736/ekonomi-indonesia-triwulan-i-2020tumbuh-2-97-persen.html.

Hendi, Renaldo. (2020, 19 Juli) "Bantuan Pemerintah di Masa Covid-19", dalam https://ombudsman.go.id/artikel/r/artikel bantuan-pemerintah-di-masa-covid-19.

Ibrahim, Abdul Malik. (2020, 30 Juni). "Dampak Covid-19 Terhadap Perekonomian dan Kebijakan Pemerintah Indonesia" dalam https://sukabumiupdate.com/detail/balewarga/opini/68505-DampakCovid-19-Terhadap-Perekonomian-dan-Kebijakan-

Pemerintah-Indonesia,

Keputusan Menteri Sosial Republik Indonesia Nomor 54/HUK/2020 Tentang Pelaksanaan Bantuan Sosial Sembako dan Bantuan Sosial Tunai dalam Penanganan Dampak Corona Virus Disease 2019 (COVID-19).

Kusnah, Wawancara, Desa Gedongarum Kecamatan Kanor Kabupaten Bojonegoro, 24 Juni 2020

Legimah, Wawancara, Desa Gedongarum Kecamatan Kanor Kabupaten Bojonegoro, 23 Juni 2020

Lestary J. Barany et al. (2020, 15 April). "Bantuan Sosial Ekonomi di Tengah Pandemi Covid-19: Sudahkah Menjaring Sesuai Sasaran?”, CSIS Commentaries.

“Pemerintah Berikan 6 Program Bantuan Tambahan Hadapi Pandemi Covid-19" (2020, 30 Juni) dalam https://setkab.go.id/pemerintah-berikan-6-program-bantuan-tambahan-hadapipandemi-covid-19/.

Peraturan Menteri Desa PDTT No. 6 Tahun 2020 tentang perubahan atas Peraturan Menteri Desa, PDTT Nomor 11 Tahun 2019 tentang Prioritas Penggunaan Dana Desa Tahun 2020

Pramanik, Nunik Dewi. (2020) "Dampak Bantuan Paket Sembako dan Bantuan Langsung Tunai Terhadap Kelangsungan Hidup Masyarakat Padalarang pada Masa Pandemi Covid 19". Dalam Intelekva: Jurnal Ekonomi, Sosial \& Humaniora. Vol. 1 No. 2

Priadi Asmanto et al. (2020, April). "Ringkasan Kebijakan Penggunaan Dana Desa:Bantuan Langsung Tunai Desa", Unit Riset, TNP2K. 
Spirit Publik Volume 15, Nomor 2, 2020

Halaman 97-110

P-ISSN. 1907-0489 E-ISSN 2580-3875

Purwanto, Wawancara, Desa Gedongarum Kecamatan Kanor Kabupaten Bojonegoro, 25 Juni 2020

Sarmini, Wawancara, Desa Gedongarum Kecamatan Kanor Kabupaten Bojonegoro, 24 Juni 2020

Setiawan, Koesworo. (2020, 7 Juli). "Mekanisme Penyaluran Bansos Penuhi Prinsip-prinsip Akuntabilitas" Dalam https://kemsos.go.id/mekanisme-penyaluran-bansos-penuhiprinsip-prinsip-akuntabilitas

Siti Suwarni, Wawancara, Desa Gedongarum Kecamatan Kanor Kabupaten Bojonegoro, 23 Juni 2020 